\title{
A konnektivitás mint fegyver. Kína és Ausztrália aszimmetrikus kereskedelmi kapcsolatainak példája
}

Connectivity as a Weapon. The Example of Asymmetric Trade Relations Behween China and Australia

Csenger Ádám - Eszterhai Viktor

https://doi.org/10.47707/Kulugyi_Szemle.2021.2.2

Összefoglaló: Kína és az Amerikai Egyesült Államok nagyhatalmi versengése akár egy új hidegháború felé is sodorhatja a világot, ami egyetlen régió számára sem jelent annyi veszélyt, mint Kelet-és Délkelet-Ázsia országainak, amelyek politikai és katonai szempontból inkább az Egyesült Államokhoz, a gazdasági kapcsolatok intenzitása tekintetében pedig Kínához kötődnek. A tanulmány központi kérdése, hogy Kína milyen eszközökkel tud a régió országaira nyomást gyakorolni annak érdekében, hogy a politikai orientációjukat megváltoztassa. A szerzők hipotézise, hogy e cél eléréséhez Kína számára a gazdasági konnektivitás a legracionálisabb választás. Az Ausztrália és Kína közötti kereskedelmi kapcsolatok esettanulmányán keresztül bemutatjuk e stratégiának a gyakorlatba ültetését és nyomásgyakorló eszközként való használatát. A tanulmány konklúziója, hogy a konnektivitás alkalmas ugyan a politikai nyomásgyakorlásra, de egyértelmú korlátai is vannak.

Kulcsszavak: Kína, Ausztrália, geoökonómia, függőség, aszimmetria

Abstract: The great power rivalry between China and the United States of America could push the world lowards a new Cold War which poses no greater a threat to any other region than East and Southeast Asia, which are more closely linked to the United States in political and military terms and to China regarding the intensity of economic relations. The central question of this study is how China can put pressure on the countries of the region in order to change their political orientation. The hypothesis of the authors is that economic connectivity as a tool is the most rational choice for China to achieve this goal. We illustrate the practical application of this strategy and its use as an instrument for pressure with the case sludy of Australia-China trade relations. The conclusion of the 


\section{Külïgyi Szemle}

paper is that while connectivity can be used to exert political pressure, it has clear limilations.

Keywords: China, Australia, geoeconomics, dependence, asymmetry

\section{Az új hidegháború és Kelet-Délkelet-Ázsia}

Mike Pence amerikai alelnök 2018 októberében tartott nagyhatású beszédében élesen kritizálta a Kínai Népköztársaság külpolitikai gyakorlatát: azzal vádolta Pekinget, hogy asszertív külpolitikájának a célja a geopolitikai térszerzés és saját nemzetközi befolyása kiterjesztése az Egyesült Államok globális pozíciójának a rovására. A beszéd kritikus hangneme jelentős nemzetközi figyelmet eredményezett, és a külvilág egy új hidegháború nyitányaként aposztrofálta (Heydarian, 2020). Habár Pence a korábbiaktól eltérô módon, nyíltan vádolta Kínát, valójában az elmondottak egy hosszabb folyamat, a változó ame rikai Kína-percepció újabb állomásának tekinthetők. A Peking kapcsán tapasztalható pesszimizmus oka, hogy a 2007-2008-as nyugati pénzügyi válság nyomán megkérdőjeleződött a nyugati elit által sokáig vallott tétel, miszerint Kínának a globalizált világgazdaságba történő integrálódása az univerzálisnak tekintett piacgazdasági és demokra tikus politikai reformokat fogja eredményezni az ázsiai országban is.

Az Obama-adminisztráció a felszínen továbbra is támogatta Amerika és Kína együttműködését, ugyanakkor biztonságpolitikai téren konkrét lépéseket tett Peking feltartóztatására. Ez utóbbit jól tüikrözi Barack Obama és kormánya „Pivot to Asia” (2011) külpolitikai koncepciója, illetve a Transz-csendes-óceáni Partnerségi Megállapodás (Trans-Pacific Partnership, TPP) nevű szabadkereskedelmi egyezmény támogatása. Az előbbi célja az USA külpolitikai fókuszának a Kelet-Ázsiába való áthelyezése volt - a védelmi erők jelentős átcsoportosításával -, az utóbbié pedig egy amerikai szabályokon nyugvó gazdasági zóna létrehozása a csendes-óceáni térségben (Zhao, 2012; Löfflmann, 2016). 
Donald Trump adminisztrációja már nem folytatta elődje szemér mességét; ennek egyik legfőbb oka Hszi Csin-ping kínai elnök egyre asszertívabb, a nemzetközi rendet is átalakítani szándékozó külpolitikája volt. A 2017 decemberében kiadott amerikai nemzetbiztonsági stratégia (National Security Strategy, NSS) Kínát a fennálló rendet veszélyeztető „revizionista hatalomként” és így értelemszerúen az USA „stratégiai versenytársaként" azonosította, kimondva, hogy az ázsiai ország további felemelkedése ellentétes az amerikai érdekekkel ( $\mathrm{Na}$ tional Security Strategy Archive, 2017). E törekvésekkel összhangban a Trump-adminisztráció 2018-ban kereskedelmi háborút robbantott ki, amely egy egyre nyíltabb nagyhatalmi versengés kezdetét jelentette; ennek keretében az amerikai kormány megfogalmazta a Kínai Kommunista Párt megdöntésének szükségességét is (Pompeo, 2020).

Bár a 2021 januárjában hatalomra került Joe Bidentől és admi nisztrációjától a nemzetközi közösség azt várta, hogy valamelyest csökkenti a két fél közötti feszültségeket, az első hónapok eseményei azt jelezték, hogy a Trump-időszak nullösszegú Kína-politikája alapvetően folytatódni fog. Mindezek tükrében mára egyértelmúvé vált, hogy az USA új „hidegháborús” politikájának stratégiája nem sokban különbözik a Szovjetunióval szemben alkalmazottól. E stratégia sarokkövei: a szövetségesi rendszer Kínával szembeni mozgósítása, Pe king nemzetközi megítélésének rombolása (lásd: Covidl9-narratíva), továbbá az ideológiai dimenzió beemelése a konfliktusba (autoriter elnyomó rezsimek kontra szabad demokráciák).

Annak ellenére, hogy a Washington és Peking közti rivalizálást gyakran egy új hidegháború nyitányaként azonosítják, valójában megfigyelhető egy alapvető különbség az akkori és a mostani helyzet között. A globalizáció eredményeként ugyanis az 1990-es évekre létre jött egy egységes, a szereplőket számtalan szállal összekapcsoló világgazdasági rendszer. Ebben a megváltozott környezetben a két vezető hatalom új geopolitikai versenyfutása - a klasszikus hatalmi eszközök alkalmazása mellett - egyre inkább az összekapcsoltságra fókuszál, így a biztonság és az egymással való kapcsolatokból fakadó előnyök (például gazdasági növekedés) nem választhatók el egymástól (Roberts, 


\section{Külïgyi Szemle}

Moraes és Ferguson, 2018). Ebben a sokak által a geoökonómia kor szakaként azonosított világban a korábbi, blokkokat építő nagyhatalmi törekvéseket rendkívüil megnehezíti a szereplők komplex függósége. Az Egyesült Államoknak a globalizáció jelentette kihívásokra adott válasza rendkívüil egyszerû: célja az ún. leválás részeként a kínai gazdasági kapcsolatainak a lazítása, ami az előfeltétele annak, hogy az USA és szövetségesei csökkenteni tudják az ázsiai nagyhatalomnak való kitettségüiket.

Peking stratégiájának a megértéséhez nem elég az előző hidegháború tapasztalataihoz fordulnunk. Bár az elmúlt évtizedben a kínai hadsereg technológiai színvonala és erőkivetítő képessége jelentősen nőtt, esetében továbbra is jóformán csak egy regionális katonai hatalomról beszélhetünk. A kínai külpolitika emellett hagyományosan elutasitja a katonai szövetségkeresést és a blokkok építését. Noha az utóbbi években Kína bizonyos országok (Oroszország, Pakisztán) felé a katonai együttműködés terén is jelentős lépéseket tett, formális szövetségkötésre továbbra sem került sor. Mindemellett az ország továbbra sem említ ellenséget, és az ideológiaexportra is nehéz példát találni.

Kína ugyanakkor mára szinte minden tekintetben a világgazdaság meghatározó szereplője; gazdasági potenciálja és technológiai fejlettsége messze meghaladja a Szovjetunióét. Az ország gazdasági ereje nagyrészt a globalizáció eredménye, így annak továbbra is elkötele zett támogatója. Mindezek miatt számos elemzô azt állítja, hogy Peking stratégiája nem érthető meg a klasszikus geopolitikai terminusok alapján, hanem jobban megfelel a geoökonómia korának. E nézetek szerint Kína célja az összekapcsoltság erősítése - amely normál esetben csupán látens módon, de kritikus esetekben akár aktív zsarolási potenciálként is felhasználható. A tanulmány központi kérdése, hogy ez a stratégia valóban azonosítható-e a kínai külpolitikában. Ennek megállapításához a legjobb eszköz egy olyan esettanulmány vizsgá lata, amelyben Kína a konnektivitást valóban fegyverként használja.

A hidegháború felé sodródás értelemszerűen súlyos következményekkel jár a globalizált világ minden részén, de különösen Kelet- és 
Délkelet-Ázsiában. Mindenekelőtt azért, mert a régió az Indocsendes-óceáni térség részeként az utóbbi évtizedekben a globalizált világgazdaság centrumává vált. Emellett Kínának a régióval fennálló mély gazdasági kapcsolatai nyomást gyakorolnak az USA biztonsági szövetségi rendszerére, mivel az ott fekvő országok jelentős része ez utóbbinak a kulcsfontosságú tagja. A második világháború után az Egyesült Államok által létrehozott biztonsági architektúrára, illetve a Négyoldalú Biztonsági Párbeszéd (Quadrilateral Security Dialogue, Quad) nevú újabb, a régiót szélesebben értelmező, az USA-t, Japánt, Ausztráliát és Indiát magában foglaló formációra Kína az érdekei érvényesítését gátolni próbáló eszközként tekint, amelyet stratégiai szempontból semlegesítenie kell (Lukin, 2019; Wuthnow, 2019).

A feszüiltségek által az egyik leginkább érintett állam a Kelet-és Délkelet-Ázsiához egyre szervesebben kapcsolódó Ausztrália. A kontinensnyi ország egyfelől a régió déli féltekére eső középhatalma, hagyományosan angolszász politikai és biztonságpolitikai kötődéssel, valamint rendkíviul szilárd nyugati értékrenddel. Mindezek alapján az USA egyik legfontosabb szövetségese és a Quad tagja. Másfelől viszont Ausztrália és Kína gazdasága az utóbbi néhány év során rendkíviul szorosan összefonódott, ami az utóbbi ország gazdasági méretéból fakadóan súlyos aránytalanságokhoz vezetett. Mindezek következtében Ausztrália rendkívïl kényes helyzetbe kerüilt, amelyet egyrészt az amerikai és a saját politikai érdekei és elvi álláspontjai, másrészt a gazdasági érdekei közötti egyensúlyozás jellemez. Ausztrália a különleges státusza miatt a kínai geoökonómiai nyomásgyakor lás egyik legjobb terepe - a két ország közötti, egyre konfliktusosabbá váló politikai helyzet miatt egy ideje gyakran visszatérő vád is lett, hogy Kína gazdasági eszközökkel igyekszik nyomást gyakorolni Ausztráliára (Iain, 2020; Suri, 2020). Mindezek következtében Ausztrália jó esettanulmányként szolgál Kína konnektivitáson alapuló nyomás gyakorlásának a vizsgálatához, és a példája hozzájárul ahhoz, hogy a kelet-és délkelet-ázsiai országok számára is releváns tanulságokat vonjunk le Kína stratégiája kapcsán. 


\section{Külïgyi Szemle}

A tanulmány külön hangsúlyt fektet arra a kérdésre, hogy a konnektivitás nyomásgyakorlásként történő használatának milyen korlátai vannak. Ehhez első lépésként áttekintést nyúijtunk a geoökonómia elméletéról, majd pedig feltárjuk azokat a gazdasági körülményeket és kapacitásbéli küilönbségeket, amelyek lehetővé teszik Kína számára, hogy a gazdasági erejére támaszkodva politikai nyomást gyakoroljon Ausztráliára. A kínai befolyás csökkentése érdekében 2018-ban bevezetett ausztrál intézkedések óta a kétoldalú kapcsolatok lejtmenetbe kerültek. A tanulmány az azóta alkalmazott legfontosabb kínai gazdasági nyomásgyakorló eszközök ismertetése révén bemutatja Kína stratégiájának főbb lépéseit. Ezt követően kijelöli a geoökonómia he lyét és szerepét Peking külpolitikai stratégiájában, s egyben rávilágít az alkalmazásának a korlátaira is. Végezetuil a szerzők levonják a következtetést azzal kapcsolatban, hogy az amerikai-kínai nagyhatalmi vetélkedés milyen hatással lehet Kelet- és Délkelet-Ázsiára a geoökonómia korában.

\section{A geoökonómia elmélete és Kína mint geoökonómiai nagyhatalom}

A geoökonómia kifejezés a hidegháború végét követően vált népsze rűvé, amikor felismerték, hogy a más államok viselkedését befolyá solni leginkább képes tényező szerepkörét a globalizált világban a katonai hatalom átadta a gazdaságinak (Luttwak, 1990). A gazdasági eszközök politikai célból történő alkalmazására természetesen számtalan korábbi történelmi példa akad, a geoökonómia megközelítése szerint azonban lényeges küilönbség, hogy a globalizáció következtében létrejött összekapcsoltság miatt a gazdasági eszközök a politika elsődleges eszközeivé váltak (Findlay és O’Rourke, 2009). Bár az összekapcsoltságra a hidegháború után a gazdasági növekedés és a globális béke zálogaként tekintettek, a kölcsönös függőségek nemzetbiztonsági kockázatkénti azonosítása - mindenekelőtt a nagyhatalmi versengés következményeként - a 2010-es évek után egyre gyakoribbá vált. Az egymásrautaltság e negatív hatásának a felismerésén alapult a 
Trump-adminisztráció Kína-politikája, amelynek egyik meghatározó célja a Kínával ápolt kapcsolatok lazítása és ezáltal a kitettség csök kentése volt.

A kölcsönös függőségek az államok céljait is átalakítják, mert lehetetlenné teszik az abszolút nyereség megszerzését egy konfliktushelyzetben. A legtöbb, amit az államok el tudnak érni, hogy a másik félhez képest kisebb veszteséget szenvednek el (ez az ún. relatív veszteségek elve) (Roberts et al., 2018). A szereplők a függőségre épülő gazdasági eszközöket jellemzően akkor vetik be fegyverként egymás ellen, ha a kapcsolat a saját javukra aszimmetrikus. Az államok sokféleképpen használják a gazdasági eszközöket a külpolitikai céljaik elérése érdekében. A gazdaságdiplomácia mellett a legtöbb gazdasági eszköznek van ösztönző és kényszerítő oldala is. Ösztönző eszközök például az export- vagy importtámogatások, a kedvezỏ tarifadiszkriminációk, a pénzüigyi támogatások, a beruházások stb. A kényszerítő eszközöket többek között a vámtarifa-emelések, az embargók, a bojkottok, a feke telisták, az engedélyek elutasítása és az eszközök befagyasztása jelentik (Baldwin, 1985; Norris, 2016; Blackwill és Harris, 2017).

Bár a geoökonómia sokáig a gazdasági eszközök politikai célra tör ténő alkalmazását emelte ki, az újabb irányzatok már a konnektivitás minden területét a szereplők viselkedésének a megváltoztatására alkalmas eszköznek tekintik (Kahler és Kastner, 2006). A geoökonómia ezen új megközelítése szerint a világban lényegében konnektivitási háborúk zajlanak, amelyekben az egyes nagyhatalmak célja, hogy relatív hatalomra tegyenek szert a regionális piacok egyesítésével és így az aszimmetrikus együttmúködésük elmélyítésével (Leonard, 2016). A legfontosabb stratégiai elemek közé tartozik a fent felsorolt eszközökkel történő gazdasági hadviselés és kapcsolatépités, a nemzetközi intézmények kiterjesztése és más szereplőkkel szembeni használata, továbbá a nagyhatalom központi helyzetét erősitő infrastruktúra kialakítása. A geoökonómia föként azoknak a domináns szereplőknek a politikai eszköze, amelyeknek más államokkal szemben erős a relatív gazdasági helyzetük, vagy rendelkeznek más szereplők számára kritikus erőforrással (Kahler és Kastner, 2006; Leonard, 2016). 


\section{Külïgyi Szemle}

Kevés olyan állam akad, mint Kína, amely egyértelműen geoöko nómiai szuperhatalomnak tekinthető. A kínai a világ második legna gyobb nemzetgazdasága, a legnagyobb kereskedő nemzet, a világ ipari termelésének a központja és a Föld leggyorsabban növekvő fogyasztói piaca. Az ország mélyen integrálódott már a globális értékláncokba és kereskedelembe. A 2007-2008-as pénzügyi válság óta a közvetlen küilföldi befektetések egyik fő forrása, ami egyre több régióban kérdőjelezi meg a klasszikus donorországok, például az Egyesüilt Államok vagy Japán helyzetét. A kapacitásai alapján Kína - Amerikát és az Európai Uniót leszámítva - minden állammal képes aszimmetrikus gazdasági kapcsolat kialakítására, a világgazdaság egyes szektoraiban betöltött központi szerepe miatt pedig még az USA és az EU is tőle függ.

A gazdasági erőnek a külpolitikai célok elérése érdekében történő mozgósítása különösen hatékonynak tűnik egy olyan állam esetében, amelyben a vezető erő, a Kínai Kommunista Párt (KKP) megkérdőjelezhetetlen politikai hatalommal rendelkezik. A „szocializmus kínai sajátosságokkal" elnevezéssel illetett politikai berendezkedésből fakadóan a KKP értelemszerűen irányító szerepet tölt be a gazdaságon belïl is, amely könnyen a külpolitika szolgálatába állítható. Mindez a legegyértelmúbb formában az állami tulajdonban lévő vállalatok és pénzügyi szereplők viselkedésén keresztül érvényesül. Kína mindemellett jelentős energiákat fektet a párhuzamos nemzetközi pénzügyi intézmények (például az Ázsiai Infrastrukturális Beruházási Bank) létrehozásába, amelyek a Bretton Woods-i rendszer intézményeihez hasonló funkciókat töltenek be. Végüil pedig a grandiózus Övezet és Út Kezdeményezés (Belt and Road Initiaitive, BRI) kimondott célja a konnektivitás építése - helyi és regionális politikák koordinációján, infrastruktúra-fejlesztésen, kereskedelmen, valamint a pénzügyi és humán szférán keresztuil -, amellyel Peking Ázsia, Európa és Afrika kapcsolatrendszerét igyekszik átalakítani (Rolland, 2017). A gazdasági eszközök külpolitikai felhasználása Kína esetében azért is tűnik racionális választásnak, mert az ország a növekvő katonai kapacitásai ellenére továbbra sem tudja felvenni a versenyt az USA globális erőkivetítő képességeivel. 
A geoökonómia szakirodalma mindezért gyakran utal referenciaként Kínára (Zhang és Keith, 2017; Baru, 2012; Beeson, 2018), sôt olykor a „geoökonómia kínai jellemzőkkel” kifejezés is felbukkan (Wu, 2016), mindenekelőtt a BRI kapcsán. Más szerzők azonban óvatosabban fogalmaznak ezzel kapcsolatban. Egyes szakértők kételkednek abban, hogy Kínának átfogó, hosszú távú külpolitikai stratégiája vagy nagy terve lenne (Wu, 2016; Ferchen, 2016). Mások azzal érvelnek, hogy Kína nem egy monolit állam, amely mindenben a KKP utasításai szerint múködik, így ha Peking rendelkezik is geoökonómiai stratégiával, azt nem feltétlenuil képes hatékonyan megvalósítani (Jones és Zeng, 2019; Eszterhai, 2021). Végüil egyesek amellett érvelnek, hogy a kínai geoökonómiai stratégiát külföldi szakértők „hozzák létre”, és az lényegében nem más, mint egy geopolitikai „narratíva”, amely jól illik az amerikai-kínai nagyhatalmi versengésbe (Drezner, 2017).

Mindezek alapján körültekintő vizsgálatra van szüikség ahhoz, hogy megállapíthassuk, Kína szisztematikusan alkalmaz-e gazdasági eszközöket más országok politikájának a megváltoztatására, továbbá hogy eldöntsük, a geoökonómia Peking tudatosan használt stratégiájának tekinthető-e, amelyet a hidegháború felé sodródó kelet-és délkelet-ázsiai térségben alkalmaz a céljai elérése érdekében.

\section{Hipotézis és módszertan}

A tanulmány központi kérdése, hogy Kína milyen eszközökkel tud a kelet-és délkelet-ázsiai régió országaira nyomást gyakorolni annak érdekében, hogy azok a politikai orientációjukat megváltoztassák. Azt feltételezzük, hogy a gazdasági konnektivitás mint eszköz a legracionálisabb választás Kína számára a céljai elérése szempontjából, és ennek meg kell jelennie az Ausztráliával való kapcsolatában is. Bár a kínai-ausztrál gazdasági kapcsolatok rendkíviul szerteágazóak, a témánkhoz a legmegfelelőbbnek a kétoldalú kereskedelem vizsgálata tekinthető. Közismert, hogy az elmúlt évtizedek ausztrál gazdasági fejlődésében a kínai piac növekvő nyersanyagigénye kulcsszerepet játszott, amelynek következményeként a közvélekedés szerint 


\section{Külïgyi Szemle}

Ausztrália immár egyoldalúan függ Kínától. A kapcsolódó szakiro dalomra reflektálva az első hipotézisünk ezért a következő: Kína a kétoldalú kereskedelmi kapcsolatokban rendelkezik azzal a gazdasági kapacitáson alapuló aszimmetriával, amely képessé teszi arra, hogy nyomást gyakoroljon Ausztrália politikájára. Ez a hipotézis azt feltételezi, hogy a két ország között szorosak a kereskedelmi kapcsolatok, és az aszimmetria miatt Kína számára a konnektivitás fegyverként való használatának költsége az elfogadható tartományba esik.

A szoros és aszimmetrikus gazdasági kapcsolatok azonban önmagukban még nem elégségesek ahhoz, hogy a konnektivitás fegyverként való alkalmazásának a tényét elfogadjuk. Ezért egy második hipotézist is felállítunk, amely szerint Kína szélsóséges esetekben gazdasági eszközökkel zsarolja Ausztráliát a viselkedése megváltoztatása érdekében. Azaz a gazdasági függőség fegyverként történő esetleges felhasználása tudatos stratégia Kína külpolitikájában. E hipotézis pontos feltérképezése alapvető fontosságú lehet a kínai külpolitika fő tendenciáinak a megértéséhez, továbbá Kína, valamint a kisebb keletés délkelet-ázsiai országok viselkedésének az elkövetkezó évtizedekre vonatkozó előrejelzéséhez.

Az első hipotézis igazolása a kétoldalú kereskedelmi kapcsolatok átfogó elemzését igényli. Ehhez a 2015-ben életbe lépett kínai-ausztrál szabadkereskedelmi megállapodást tekintjük a kiindulópontnak, a végpontot pedig 2020 jelenti. Az adatok forrása a UN Comtrade (2021) adatbázisa. A második hipotézis vizsgálatához az ausztrál-kínai kapcsolatoknak a 2018 és 2021 tavasza közötti, feszültségekkel terhes időszaka szolgál esettanulmányként. Azt vizsgáljuk, hogy a kínai kormány lépései mennyire illenek bele a szakirodalomban meghatározott geoökonómiai eszköztárba (Leonard, 2016; Blackwill és Harris, 2017), illetve mennyire tekinthetők Kína szisztematikusan és célzottan alkalmazott stratégiájának. Mivel a kínai vezetés hivatalosan tagadja a gazdasági eszközök kényszerítő jellegű használatát, a kínai kereske delmi lépéseket médiahírek alapján rekonstruáljuk. 


\section{Kereskedelmi aszi mmetria Kína és Ausztrália között}

A UN Comtrade forrásai szerint Ausztrália legfontosabb kereskedelmi partnere mind a behozatal, mind a kivitel tekintetében Kína: 2020ban az áru 27 százaléka érkezett a távol-keleti országból, míg az export 41 százaléka irányult oda. Kína súlya Ausztrália külkereskedelmében a közelmúltban dinamikusan növekedett: a szabadkereskedelmi megállapodás 2015-ös életbelépése és 2020 között a kínai import értéke 75,8, az oda irányuló exporté pedig 61 százalékkal nőtt (1. ábra). Az elmúlt öt év jelentős kereskedelmi aktívumot mutatott; 2020-ban némileg visszaesett ugyan a Kínába irányuló kivitel értéke, de mivel a teljes ausztrál export terén még nagyobb csökkenés következett be, összességében az ázsiai állam súlya tovább növekedett a teljes kivitelen belüil. A két ország kereskedelmi kapcsolatának az aszimmetriáját mutatja, hogy Ausztrália súlya lényegesen kisebb: 2020-ban Kína teljes importjának csupán 5,6, exportjának pedig 2,1 százaléka irányult oda.

\section{1. ábra ${ }^{1}$}

Kína részesedése Ausztrália importjából és exportjából (2015-2020)
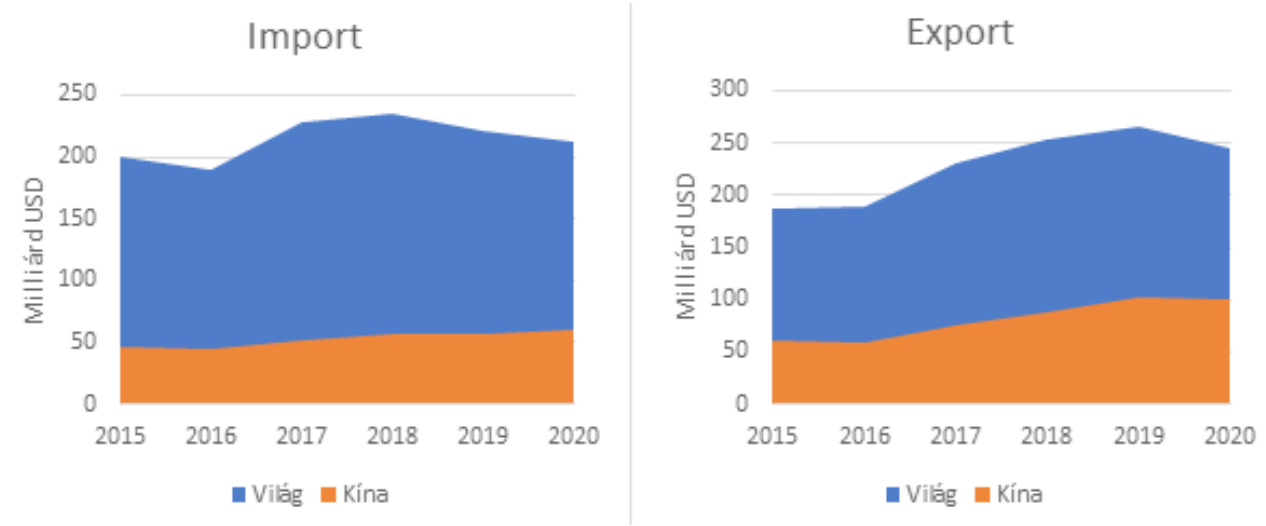

Jól mutatja az ausztrál gazdaság Kínától való kereskedelmi függését, hogy annak súlya mind az import, mind az export tekintetében nagyobb, mint a következő négy partnerországé együttesen (2. ábra).

1 Forrás: UN Comtrade, 2021. 


\section{Külïgyi Szemle}

Ezzel szemben Ausztrália Kínának csak a negyedik legfontosabb im portpartnere (Japán, Dél-Korea és az USA után), míg az export tekin tetében csupán a tizenkettedik.

\section{2. ábra ${ }^{2}$}

Ausztrália öt legfontosabb kereskedelmi partnere
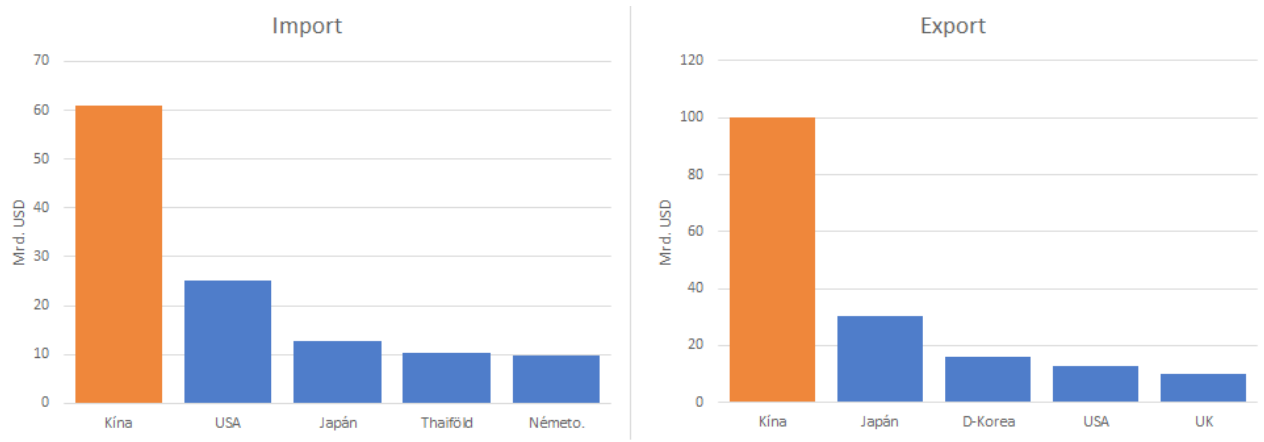

3. ábra ${ }^{3}$

Az ausztrál export legfontosabb termékeinek besorolása a SITC-kategóriák alapján

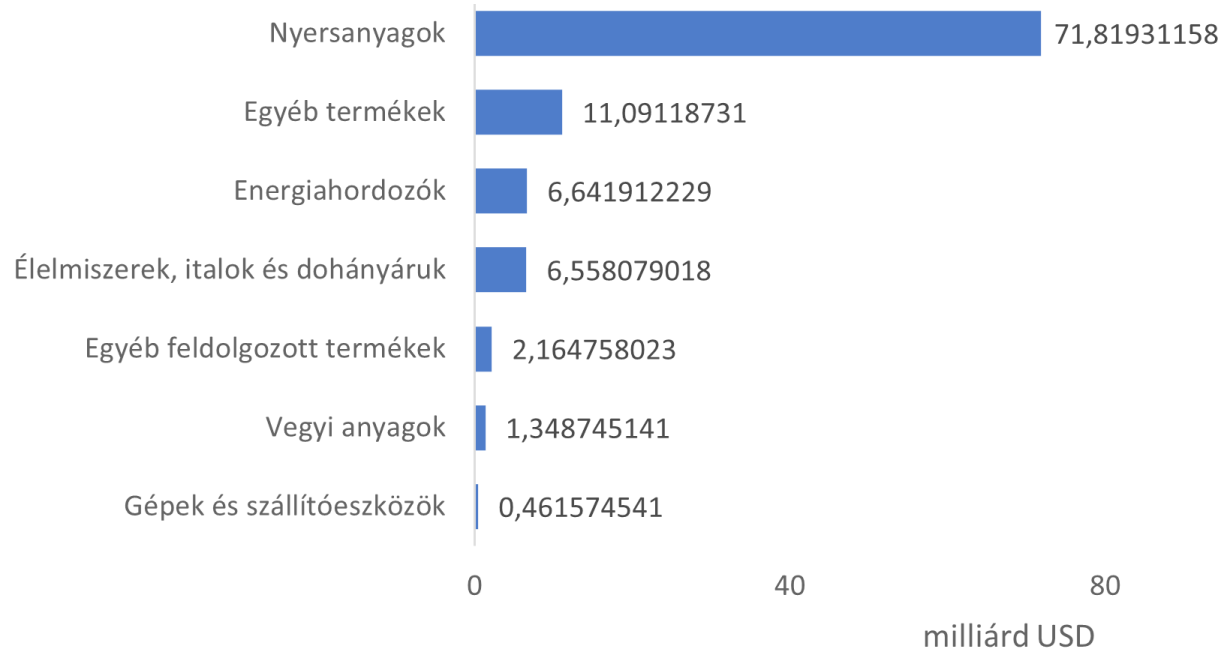

2 Forrás: UN Comtrade, 2021.

3 Forrás: UN Comtrade, 2021. 
Ausztrália legfontosabb exporttermékei (3. ábra) a nyersanyagok: a Standard International Trade Classification (SITC) besorolása szerint a kivitel 71,2 százalékát adják (SITC 2. és 4. kategória).

A legjelentősebb termékek közé a vasérc, a szén és a földgáz tar tozik, de a kínai-ausztrál szabadkereskedelmi megállapodás életbelé pése óta a mezőgazdasági termékek (marhahús, vörösbor) és a gyógyszerészeti készítmények exportja is nagymértékben nőtt. 2019-ben a Kínába exportált összes ausztrál áru több mint felét a vasérc tette ki (Australian Bureau of Statistics, 2020).

Az áruk mellett jelentős bevételi forrást jelent Ausztrália számára a szolgáltatások kereskedelme is, amit jól tükröz, hogy a Kínába irányuló szolgáltatásexport 2018-ban 5,4-szeresen múlta felül az ilyen jellegű behozatalt (UN Comirade, 2021). A szolgáltatásokon belül a külföldi diákok oktatása - amit Ausztrália exportcikként kategorizál az egyik legjelentősebb exportágazatnak számít. Az összértéke 2019 ben 28,4 milliárd dollárt tett ki, és több mint a negyedét kínai diákok fizették (Hare, 2021).

Mindezek alapján megállapíthatjuk, hogy Ausztrália és Kína ke reskedelmi kapcsolata rendkívül aszimmetrikus. Ausztráliának a kínai piactól való függősége lehetővé teszi Kína számára, hogy a kereskedelmet fegyverként használja annak érdekében, hogy politikai nyomást gyakoroljon az ausztrál kormányra.

\section{A konnektivitás fegyverként történô felhasználása a kereskedelemben}

Az aszimmetrikus kereskedelmi kapcsolatok fegyverként való felhasz nálásának a kiváltó oka, hogy Ausztrália és Kína kapcsolata 2017 óta folyamatosan romlik. 2017 közepén került nyilvánosságra, hogy a három legnagyobb ausztrál pártot már 2015-ben figyelmeztette az ál lami nemzetbiztonsági ügynökség, az Australian Security Intelligence Organisation (ASIO) arra, hogy a Kínai Kommunista Párthoz szorosan kötődő küllföldi magánszemélyek megpróbálhatnak befolyást szerez ni az ország belpolitikájára. A kirobbant botrány végül oda vezetett, 


\section{Külïgyi Szemle}

hogy 2018 decemberében egy új törvénycsomag lépett életbe, amely nek célja az ausztrál kormányban és politikában megnyilvánuló kül földi befolyás jellegének, szintjének és kiterjedésének a megjelenítése a nyilvánosság számára (Csenger, 2020). A törvény ki nem mondott célpontja Kína volt. Tovább rontotta a kétoldalú kapcsolatokat 2018 ban, hogy az ausztrál kormány kizárta a Huaweit az ország 5G-hálózatának kiépítéséből.

2020 áprilisától lett kifejezetten ellenséges a két ország viszo nya, miután Ausztrália egy Kínában lefolytatandó független vizsgálatot szorgalmazott a koronavírus-járvány eredetének a felderítésére (Scott, 2020). Ezt követően, májustól, Kína kiugróan magas vámokat, illetve importkorlátozásokat és -tilalmat vezetett be számos ausztrál exporttermékkel (például árpa, marhahús, szén, réz, gyapot, tenger gyümölcsei, cukor, rönkfa és bor) szemben (Rajah, 2021). Az intézke dések indoklása más és más volt (és ugyanazt az árut több indok alap ján is érinthették a szankciók): állami támogatással, illetve dömpinggel szembeni fellépés (például a bor és az árpa esetében); az adott áru nem felelt meg bizonyos elöírásoknak (például a szén és a rönkfa); de egyes áruk (például a szén és a gyapot) kapesán nem is volt hivatalos indoklás, viszont a hírek szerint a hatóságok arra utasították a kínai vásárlókat/felhasználókat, hogy ne vegyenek többet az adott termékekből. A kínai külügyminisztérium közlése szerint bizonyos termékekről (például bor, szén és cukor) maguk a kínai vásárlók döntöttek úgy, hogy kevesebb ausztrál terméket vesznek belőlüik (Reuters, 2020). Az újabb szankciók kivetésének a jelek szerint még nincs vége: 2021. február vége óta Kína gyakorlatilag leállította az ausztrál széna importját azáltal, hogy nem újította meg az exportőrök kiviteli engedélyét. Az ausztrál szénaexport mintegy harmada irányult eddig Kínába, évi 123 millió dollár értékben (Saunokonoko, 2021). A 2021. áprilisi hírek szerint pedig a kínai oktatási ügynökségek azt az utasítást kapták, hogy ne ajánljanak vagy hirdessenek a diákok számára ausztrál oktatási intézményeket (Hare, 2021). 


\section{A kínai importkorlátozó intézkedések hatása}

A kínai intézkedések eddigi hatásainak a felmérését nehezíti, hogy időben egybeesnek a koronavírus-járvánnyal, ugyanakkor bizonyos következtetéseket levonhatunk. Az érintett ágazatok Kínába irányuló exportjának összértéke 2019-ben mintegy 19 milliárd dollár volt, 2020-ban pedig becslések szerint csupán 4,2 milliárd, vagyis a küilönbözet közel 15 milliárd dollár (Rajah, 2021). Ez a drasztikus visszaesés ugyanakkor nem teljes egészében a kínai szankciók következménye, hanem egyéb tényezőké is, többek között a járványé. A szankcionált termékek zömének a termelőknek sikerült új piacokat találniuk: a szén, az árpa, a réz, a gyapot, a tenger gyümölcsei és a rönkfa esetében is jelentős exportdiverzifikáció ment végbe a kínai intézkedések élet belépését követően. A boripar azonban egyelőre nem tudta kiváltani az évi mintegy 900 millió dollár értékủ kínai piacot másokkal, és a marhahúsexport is visszaesett (ez viszont inkább az éveken át tartó szárazság okozta kínálati oldali problémákra vezethető vissza) (Rajah, 2021).

Összességében elmondható, hogy a kínai intézkedések által érintett termékek nagy részének az ausztrál exportőrök találtak más piacokat, így a szankciók hatása korlátozottnak bizonyult. Ami a Kínába irányuló teljes ausztrál kivitel értékét illeti, az a fó exportcikknek számító vasérc iránti nagymértékű ottani keresletnek és a vasérc magas világpiaci árának köszönhetően alig változott: 2020-ban az összér ték 111,5 milliárd dollár volt, azaz mindössze 2 százalékkal kevesebb, mint a csúcsévnek számító 2019-ben (Rajah, 2021). Mindemellett egyes intézkedéseivel Kína magának is kárt okozott: a globális hiány miatt az ausztrál importnál drágábban kénytelen beszerezni a rézér cet (Russell, 2021), a szénimportra 2020 októberében kivetett tilalom pedig decemberre oda vezetett, hogy miközben a több száz millió tonna - részben már kifizetett - ausztrál szénnel megrakott hajókat nem engedtek kikötni, az ország szénhiánnyal és ennek következté ben az utóbbi évek legsúlyosabb áramkimaradásaival küzdött (Davidson, 2020). Nem véletlen, hogy az ausztrál vasércimportot (eddig 


\section{Külïgyi Szemle}

legalábbis) nem érték retorziók, hiszen e téren a kínai igény mintegy 70 százalékát abból fedezik. A cseppfolyósított földgáz (LNG) importjára sem tűnik valószínúnek tilalom vagy korlátozás bevezetése, mivel a kínai behozatal felét Ausztrália adja (Uren, 2020).

Noha Peking hivatalosan nem azért vezette be az említett intéz kedéseket, hogy megváltoztassa Canberra Kínával kapcsolatos politi kai és gazdasági hozzáállását, több lépése is világosan mutatja, hogy mit vár el Ausztrália részéról.

2020 novemberében a kínai küilügyminisztérium Ausztráliát tet te felelőssé a megromlott kapcsolatokért, mivel szerintük az ország (egyéb barátságtalannak ítélt lépései mellett) Kína belügyeibe avatko zott be azzal, hogy szót emelt Hongkong, Hszincsiang és Tajvan kér désében, vizsgálatot sürgetett a Covid19 eredetének a felderítésére, továbbá a nemzetbiztonsági érdekeket kifogásként felhasználva helyi kínai beruházásokat akadályozott meg (Ministry of Foreign Affairs of the People's Republic of China, 2020). Néhány nappal késóbb Canber rában egy kínai diplomata az ausztrál média néhány képviselőjének átadott egy dokumentumot, amely 14 pontban sorolta fel hazájának az Ausztráliával kapcsolatos sérelmeit, amelyek alapvetően megegyeztek a kínai külügyminisztérium által megfogalmazott vádakkal. Egy kínai kormánytisztviselő pedig úgy fogalmazott, hogy országa dühös, és „ellenséggé válna, amennyiben azzá tennék".

Az ausztrál kormány - amely jó ideje sikertelenül próbálja fel venni a kapcsolatot a kínai vezetéssel a viták tárgyalás útján történő megoldása érdekében - az importkorlátozó intézkedéseket gazdasági kényszerítésnek tekinti, és nem mutatja jelét annak, hogy Kínát kien gesztelő lépéseket tervezne Mint Scott Morrison kormányfő kijelen tette, Ausztrália demokráciája, szuverenitása és értékei nem képezik alku tárgyát (Scott, 2020). Valójában a szankciókkal Kína a kívánttal éppen ellentétes hatást váltott ki: az ausztrál kormány ahelyett, hogy engedett volna a nyomásnak, az ellenállást választotta, ami politikai szempontból jó döntésnek bizonyult. Scott Morrison kijelentése, mi szerint soha nem fogja nyomás hatására feláldozni az ausztrál értéke ket (Needham, 2020), az ausztrálok többségének álláspontját tükrözi: 
közel kétharmaduk úgy véli, hazájuk az áldozat a kereskedelmi háborúban, amelyért nem terheli felelősség (Murphy, 2020).

Azt, hogy a konnektivitás fegyverként való alkalmazása Ausztrá liával szemben eddig sikertelen volt, jól szimbolizálja az a tény, hogy a szankciókkal sújtott homáripar támogatásának jegyében az auszt rálok korábban nem látott mértékben kezdték el vásárolni a helyi fogású homárt (Mcdonald, 2021). A nyomásgyakorlásával Kína ráadásul nemesak az ausztrál közvélemény zömének a szemében tûnhet úgy, mint egy olyan hatalom, amely a céljai elérése érdekében a (csak alig leplezett) nyers erő alkalmazásától sem riad vissza, hanem Ausztrália példáját látva más országok is könnyen úgy dönthetnek, hogy inkább visszafogják a Kínával fennálló kereskedelmi és gazdasági kapcsolataik bővüilését. Mindez pedig kontraproduktív Kína Kelet-és DélkeletÁzsiát érintő hosszú távú céljai szempontjából.

\section{Konklúzió}

Széles körben elfogadott nézet, hogy Kína növekvő gazdasági kapaci tása révén politikai befolyásra tehet szert. Tanulmányunk célja az volt, hogy igazolja ezt az állítást, valamint Ausztrália példáján keresztül bemutassa, miként tudja Peking a konnektivitást stratégiai eszközként felhasználni ahhoz, hogy a céljának megfelelően alakítsa más szereplők viselkedését.

Az első hipotézisünk vizsgálata során arra mutattunk rá, hogy Kína és Ausztrália között egyre mélyebb gazdasági dependencia áll fenn. Ausztráliának a kínai piactól való aszimmetrikus függősége az zal a veszéllyel jár, hogy Peking zsarolni tudja a canberrai kormányt. Esettanulmányunk rávilágított arra, hogy helytálló a nézet, miszerint a konnektivitások elmélyítése és szélsőséges esetekben fegyverként való használata a kínai külpolitikai gondolkodásban stratégiai jelentőséggel bír. Ennek fényében Kína kelet- és délkelet-ázsiai befolyás szerzésének az egyik legfontosabb eszköze az összekapcsoltság fokozása. Peking legfőbb stratégiája a gazdasági konnektivitás elmélyítése, amely egyben lehetőséget ad arra, hogy a kisebb országok viselkedését 


\section{Külïgyi Szemle}

is befolyásolja. Szélsőséges esetekben pedig azt fegyverként is tudja alkalmazni - ami az egyre feszültebbé váló nemzetközi környezetben egyre gyakrabban várható. Ausztrália esete ráadásul ebben a tekintetben nem egyedüli, mert jól illeszkedik a más államokkal (például Dél-Korea, Füilöp-szigetek) szembeni korábbi büntetőakciók sorába, így a konnektivitás fegyverként történő alkalmazása a régiós országok számára Kína hatalmát is hivatott demonstrálni.

Mindebból több fontos dologra is következtethetünk. Először is, ahogy Ausztrália példája mutatja, a konnektivitás mint fegyver egy általán nem garantálja a sikert. A gazdasági kapcsolatok megromlá sa jelentős nyomás alá helyezi ugyan a gyengébb fél kormányát, ám hozzájárulhat a népszerúsége növekedéséhez is, ami pedig politikai szempontból muníciót ad neki, hogy kitartson. Természetesen ebből a szempontból nagyon fontos tényező az időtáv. Minél tovább tart a feszültség, a költségek annál nagyobbak, viszont a konfliktushelyzet tartóssá válása arra készteti a szereplőket, hogy lazítsanak az egymáshoz fưződő szálakon, ami a konnektivitásstratégiák alapvető célját kérdőjelezi meg.

Másodszor, a nyomásgyakorlás szelektív alkalmazása - mint Ausztrália esetében a legfontosabb exportterméknek, a vasércnek a szankciókból való kihagyása jól mutatja - racionális választásnak túnik ugyan, de érdemben csökkenti a kényszerítés súlyát. Ebből kifolyólag inkább az átfogó nyomásgyakorlás bizonyulhat sikeresnek, ám ez még aszimmetria esetén is komoly károkat okozhat a nagyobb gazdaságnak - különösen akkor, ha egyes termékek kapcsán kölcsönös aszimmetria áll fenn, mint a kínai piacnak az ausztrál vasérctől való füiggősége esetében.

Harmadszor, az Ausztrália és Kína közötti kétoldalú kereskedelmi relációkat a térségbeli szabadkereskedelmi megállapodás, a Regionális Átfogó Gazdasági Partnerség (Regional Comprehensive Economic Partnership, RCEP) tükrében is érdemes vizsgálni. A kínai viselke dés felveti a kérdést, hogy egy ilyen jellegű multilaterális intézmény mennyiben tudja megvédeni a kisebb államokat Peking zsarolási potenciáljától. Ugyanakkor Kína érdeke is az, hogy a konnektivitás 
stratégiáját hủen követve, a kelet-és délkelet-ázsiai régiót egy egységes és Kína-központú kereskedelmi blokkban egységesítse.

Negyedszer, a konnektivitás fegyverként történő használatának fontos korlátja, hogy az alkalmazása rontja Kína nemzetközi megítélését, és az államokat a Kínával ápolt kapcsolataik átértékelésére és kitettségként való azonosítására készteti. Ez szélsôséges esetekben a kapcsolatok tudatos rontását vagy akár teljes megszakítását is eredményezheti.

Végezetül pedig Kína - bár nem zárja ki a katonai nyomásgyakor lás eszközét - alapvetően gazdasági téren igyekszik aláásni az USA kelet-és délkelet-ázsiai szerepét. Peking stratégiája jelentősen eltér a Washington által a Szovjetunióval szemben alkalmazott hidegháborús stratégiától (blokkok építése, katonai szövetségépítés), ami azt tükrözi, hogy a globalizáció jelentette konnektivitást minőségi küi lönbségnek tekinti a nemzetközi kapcsolatokban, amely drámaian átírja az államok közötti viszonyokat. Ez a jelentős különbség várhatóan komoly feszültségforrást jelent majd a régió országai számára, mivel egyidejűleg tapasztalják meg, hogy Kína gazdasági ereje egyre fontosabb, miközben az Egyesült Államok folyamatos nyomást gyakorol rájuk, hogy vegyenek részt a kínai felemelkedés feltartóztatásában. Mindez végeredményben bonyolult diplomáciai manőverekhez, az egyik oldalról a másikra pártoló kisállami magatartáshoz vezet.

\section{Irodalomjegyzék}

Australian Bureau of Statistics (2020). Australia's Trade in Goods with China in 2020 September 3. A letöltés ideje: 2021. április 23. https://www.abs. gov.au/articles/australias-trade-goods-china-2020.

Baldwin, David A. (1985). Economic Stalecraft. Princeton: Princeton University Press.

Baru, Sanjaya (2012). Geo-Economics and Strategy. Survival 54(3), 47-58.

Beeson, Mark (2018). Geoeconomics with Chinese Characteristics: The BRI and China's Evolving Grand Strategy. Economic and Political Studies, 6(3), 240-256. 


\section{Külïgyi Szemle}

Blackwill, Robert D. és Harris, Jennifer M. (2017). War by Other Means: Geoeconomics and Statecraft. London: The Belknap Press of Harvard University Press.

Csenger Ádám (2020). Kínai befolyás Ausztráliában. Geopolitikai Szemle, 2(1), 169-175.

Davidson, Helen (2020). More Than 50 Australian Coal Ships Remain Stranded off China's Coast Despite Power Blackouts. The Guardian.

A letöltés ideje: 2021. április 20. https://www.theguardian.com/ world $/ 2020 / \mathrm{dec} / 24 /$ more-than-50-australian-coal-ships-remainstranded-off-china-coast-despite-power-blackouts.

Drezner, Daniel W. (2017). The Ideas Industry. New York: Oxford University Press.

Eszterhai Viktor (2021). The Geopolitical Strategy of China: The Belt and Road Initiative as a Geoeconomic Umbrella. In: Nuno Morgado (szerk.), Geopolitics in the Twenty-First Century: Territories, Identilies, and Foreign Policies (57-84. o.)

Ferchen, Matt (2016). China, Economic Development, and Global Security: Bridging the Gaps, Carnegie-Tsinghua. A letöltés ideje: 2021. április 18. https:/carnegietsinghua.org/2016/12/09/china-economic-developmentand-global-security-bridging-gaps-pub-66397.

Findlay, Ronald és O’Rourke, Kevin H. (2009). Power and Plenty: Trade, War, and the World Economy in the Second Millennium. Princeton: Princeton University Press.

Hare, Julie (2021). Chinese Student Numbers to Free-Fall in 2021. Australian Financial Review. A letöltés ideje: 2021. április 23. https://www.afr. com/policv/health-and-education/chinese-student-numbers-to-freefall-in-2021-20210228-p576ji.

Heydarian, Richard Javad (2020). The New Cold War: Sleep-Walking into Great Power Conflict. In: Richard Javad Heydarian (szerk.), The IndoPacific: Trump, China, and the New Struggle for Global Mastery (149-199. o.) Iain, D. Henry (2020). Adapt or Atrophy? The Australia-U.S. Alliance in an Age of Power Transition. Contemporary Politics, 26(4), 402-419.

Jones, Lee és Zeng, Jinghan (2019). Understanding China's 'Belt and Road Initiative': Beyond 'Grand Strategy' to a State Transformation Analysis. Third World Quarlerly, 4O(8), 1415-1439.

Kahler, Miles és Kastner, Scott L. (2006). Strategic Uses of Economic Interdependence: Engagement Policies on the Korean Peninsula and Across the Taiwan Strait. Journal of Peace Research, 43(5), 523-541. 
Leonard, Mark (2016). Connectivity Wars: Why Migration, Finance and Trade Are the Geo-Economic Battlegrounds of the Future. European Council on Foreign Relations. A letöltés ideje: 2021. április 17. https:// www.ecfr.eu/publications/summarv/connectivity_wars_5064.

Löfllmann, Georg (2016). The Pivot Between Containment, Engagement, and Restraint: President Obama's Conflicted Grand Strategy in Asia. Asian Securily, 12(2), 92-110.

Lukin, Alexander (2019). The US-China Trade War and China's Strategic Future. Survival, 61(1), 23-50.

Luttwak, Edward N. (1990). From Geopolitics to Geo-Economics: Logic of Conflict, Grammar of Commerce. The National Interest, (20), 17-23.

Medonald, Joshua (2021). Australia-China Trade Tensions Persist with Cancelled Agreements and Sharp Statements. The Diplomat. A letöltés ideje: 2021. április 30. https://thediplomat.com/2021/05/australiachina-trade-tensions-persist-with-cancelled-agreements-and-sharpstatements.

Ministry of Foreign Affairs of the People's Republic of China (2020). Foreign Ministry Spokesperson Zhao Lijian's Regular Press Conference on November 17, 2020. A letöltés ideje: 2021. április 20. https://www. fmpre.gov.cn/mfa_eng/xwfw_665399/s2510_665401/t1833054.shtml.

Murphy, Katharine (2020). Essential Poll: Two-Thirds of Australians Think Canberra Is Victim in Trade War with Beijing. The Guardian. A letöltés ideje: 2021. április 26. https://www.theguardian.com/australianews $/ 2020 / \mathrm{dec} / 15 /$ essential-poll-two-thirds-of-australians-thinkcanberra-is-victim-in-trade-war-with-beijing.

National Securily Strategy Archive (2017). National Security Strategy of the United States of America. A letöltés ideje: 2020. augusztus 12. http:// nssarchive.us/wp-content/uploads/2020/04/2017.pdf.

Needham, Kirsty (2020). Australia Won't Be Intimidated in Row with China: PM Morrison. Reuters. A letöltés ideje: 2021. április 26. https:/www. reuters.com/article/us-australia-china-idUSKBN23I1BS.

Norris, William J. (2016). Chinese Economic Stalecraft: Commercial Actors, Grand Strategy, and State Control. Ithaca: Cornell University Press.

Pompeo, Michael R. (2020). Remarks at the Richard Nixon Presidential Library and Museum: 'Communist China and the Free World's Future'. The Richard Nixon Presidential Library and Museum, July 23. A letöltés ideje: 2021. április 25. 


\section{Külïgyi Szemle}

Rajah, Roland (2021). The Big Bark But Small Bite of China's Trade Coercion. The Interpreter. A letöltés ideje: 2021. április 23. https:/www. lowvinstitute.org/the-interpreter/big-bark-small-bite-china-s-tradecoercion.

Reuters (2020). Timeline: Tension Between China and Australia over Commodities Trade. A letöltés ideje: 2021. április 25. https:/www. reuters.com/article/us-australia-trade-china-commodities-timidUSKBN28LOD8.

Roberts, Anthea, Moraes, Henrique Choer és Ferguson, Victor (2018). Geoeconomics: The Variable Relationship Between Economics and Security. Lanyfare Instilute. A letöltés ideje: 2021. április 25. https:// www.lawfareblog.com/geoeconomics-variable-relationship-betweeneconomics-and-security.

Rolland, Nadège (2017). China's "Belt and Road Initiative": Underwhelming or Game-Changer? The Washington Quarlerly, 4O(1), 127-42.

Russell, Clyde (2021). Column: China Fails to Learn from Trump Backfire in Trade War, Is Losing Against Australia. Reuters. A letöltés ideje: 2021. április 25. https://www.reuters.com/article/us-column-russellcommodities-china-aust-idUSKBN29WOHE.

Saunokonoko, Mark (2021). Australia's \$160m Hay Exports to China Under Threat As Permits Lapse. 9News. A letöltés ideje: 2021. április 26. https://www.9news.com.au/national/hav-grower-export-to-chinaunder-threat-as-permits-lapse-australian-agriculture-news/059fcc54ba7d-4c0e-8891-75c2be729cf7.

Scott, Jason (2020). Australia PM Defiant After China Airs 14 Grievances. Bloomberg. A letöltés ideje: 2021. április 25. https:/www.bloomberg. com/news/articles/2020-11-19/morrison-defiant-after-china-airs-14grievances-with-australia.

Suri, Navdeep (2020). Australia-China Relations: The Great Unravelling. ORF Issue Brief, 366, 1-16.

UN Comırade (2021). Database. United Nations. A letöltés ideje: 2021. április 21. https:/comtrade.un.org/data/.

Uren, David (2020). Australia's Asymmetrical Trade with China Offers Little Room to Move. The Strategist. A letöltés ideje: 2021. április 25. https:// www.aspistrategist.org.au/australias-asymmetrical-trade-with-chinaoffers-little-room-to-move/. 
Wu, Xinbo (2016). China's Geo-Economic Power. In World Economic Forum, Geo-Economics with Chinese Characteristics: How China's Economic Might Is Reshaping World Politics (7-8. o.) A letöltés ideje: 2021. április 16. http://www3.weforum.org/docs/WEF_Geoeconomics with Chinese Characteristics.pdf.

Wuthnow, Joel (2019). U.S. "Minilateralism" in Asia and China's Responses: A New Security Dilemma?.Journal of Conlemporary China, 28(115), 133 150 .

Zhang, Xiaotong és Keith, James (2017). From Wealth to Power: China's New Economic Statecraft. The Washington Quarlerly, 4O(1), 185-203.

Zhao, Suisheng (2012). Shaping the Regional Context of China's Rise: How the Obama Administration Brought back Hedge in Its Engagement with China. Journal of Contemporary China, 21(75), 369-89. 